\title{
混合砂河床における流量変化による 河床波を有する移動床系の応答予測と遅れ性状 \\ PREDICTION OF ALLUVIAL SYSTEM WITH SAND WAVES UNDER UNSTEADY CONDITIONS IN GRADED SEDIMENT BED
}

\author{
三輪 $\quad$ 浩 ${ }^{1} \cdot$ 大同淳之 $^{2} \cdot$ 加藤一平 $^{3}$ \\ Hiroshi MIWA, Atsuyuki DAIDO and Ippei KATO \\ 1正会員 工博 舞鶴工業高等専門学校助教授 建設システム工学科（テ625-8511 京都府舞鶴市白屋234） \\ 2正会員 工博 立命館大学教授 理工学部土木工学科（テ525-8577 滋賀県草津市野路東1-1-1） \\ 3 正会員 工修 パシフィックコンサルタンツ(株） 第三技術部（†532-0011 大阪市淀川区西中島4-3-24）
}

\begin{abstract}
Temporal responses of sand waves, mean flow depth and reach averaged sediment transportation rate due to periodic change of flow discharge were investigated on the basis of flume tests using the graded and the uniform sediment. They were also predicted by taking the reference grain size for sand wave transformation into account. The predicted results were verified with the experimental results. From the results of experiments and predictions, it was found that the width of loop in the graphs of dischargewave height and discharge-flow depth for the graded sediment were smaller than that for the uniform one under same flow discharge condition. Therefore, time lag of response for the graded sediment is smaller than that for the uniform one. And, the peaks of wave length, wave height and flow depth indicated the positive time-lag to the peak of flow discharge, while the peak of sediment transportation rate indicated the negative time-lag to it.
\end{abstract}

Key Words : unsteady flow, graded sediment bed, sand waves, transformation process, reference grain size, time-lag of response

\section{1. 緒 言}

河床波を有する移動床流れ場では，定常な流量条件の 下でも水流，流砂および河床波形状が相互に作用し合っ て複雑な系を成しているが，実河川を考えたとき，とく に洪水時のように非定常な流量条件の下では河床波が 時々刻々変形し, これが水流や流砂に影響を及ぼすため に現象はより一層複雑になる.このような問題に対して は, 流量変化に伴う河床波の変形過程と応答遅れの特性 を明らかにし，適切な予測を行う必要がある. 芦田ら1) や中川ら2) は河床波の変形過程の算定式を提案するとと もに，これを移動床流れ場の基礎式に導入して流量変化 に対する移動床系の応答を解析し, 流量と河床波形状あ るいはそれらに支配される水深との間にループが形成さ れることを示した. また，澤井3は周期的に変化する流 量条件の下で実験を行い，河床波や水深の応答遅れの特 性を流量の変化周期との関係の観点から検討するととも に, 水位流量曲線のループには水面勾配の変化によるも のだけでなく河床波の応答遅れも顕著に反映されること を示した.
以上のように, これまでの研究によって河床波の変形 過程とこれに付随する水深の応答特性はかなり明らかに されてきた. しかし，これらの研究ではそのほとんどが 河床砂は一様砂として扱われ, 混合砂の効果を検討した ものは少ない. 鈴木ら4) は一様砂河床で定常な河床波を 発達させた水路に，一様砂の平均粒径の約 3 倍の粒径を 有する砂を5\%混入した砂を給砂した結果, 波高が約 40\%低下することを見いだした．また，著者ら5，6),7)は 定常流量下の河床波の発達過程や流量急変による変形過 程を，ほぼ同一の平均粒径を有する混合砂と一様砂を用 いて比較し，とくに波高に関してかなりの相違が見られ ることを示すとともに, 粗砂や細砂の存在が河床波の変 形に影響を及ぼしていることを指摘した. さらに, 著者 ら8)は図-1に示すような台形状に変化する流量条件の下 での河床波の変形過程と移動床系の応答予測に際して,

一様砂に対しては平均粒径を, 混合砂に対しては平均粒 径の2倍の粒径を代表粒径とすることによって混合砂河 床, 一様砂河床ともほぼ啇切に予測し得ることを示すと ともに, 流れ場の変化に対する追随性の相違を明らかに した. ただ, 台形状の流量変化では一定流量区間の定常 


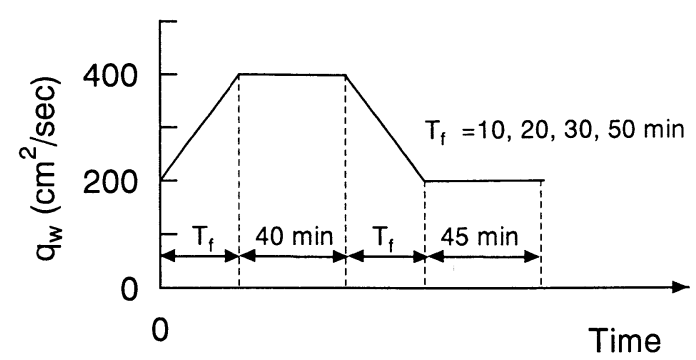

図-1 台形状流量波形 ${ }^{8)}$

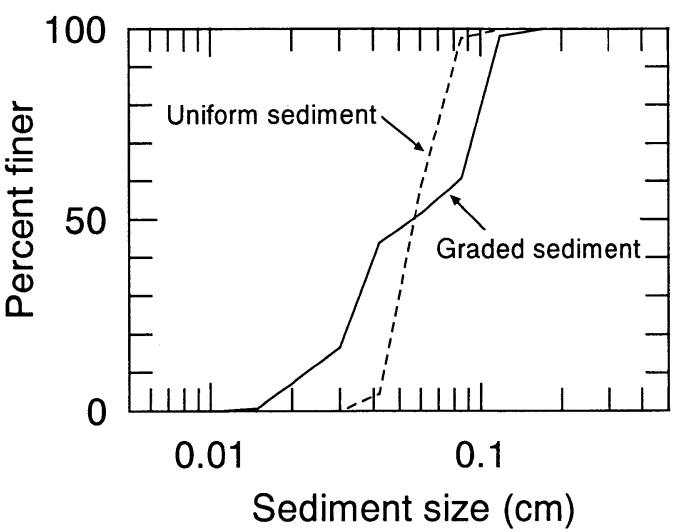

図-2 使用砂の粒度分布

流下での河床波の発達過程を含むので必ずしも連続的な 非定常流を再現しているわけではない，また，洪水流を 想定したピーク流量時からの応答遅れを考えるためには 流量増加と流量減少が連続的に接続するような流れの場 を設定する必要がある.

そこで, 本研究では混合砂河床を対象として, 正弦波 状の流量変化の下での河床波の変形過程と移動床流れ場 の応答に関する実験と予測を行い，一様砂河床の場合と 比較・検討するするとともに，流量変化に対する応答遅 れの特性について検討する.

\section{2. 実験の概要}

実験は自動流量制御装置を有する長さ $9 \mathrm{~m}$, 幅 $0.2 \mathrm{~m}$, 深 さ0.3mのアクリル製可変勾配水路を用いて行った. 本研 究は混合砂河床における現象に重点を置いているが，混 合砂が河床波の変形に及ぼす影響を明確にするため，ほ ぼ同一の平均粒径を有する一様に近い砂を用いた実験も 実施した. 実験に使用した砂の粒度分布を図一に示す. 混合砂は平均粒径 $d_{m}=0.066 \mathrm{~cm}$, 幾何標準偏差 $\sigma_{g}=1.87$ を, 一様砂は $d_{m}=0.062 \mathrm{~cm}, o_{g}=1.24$ を有する. なお， 砂の比重 $\sigma / \rho$ はいずれも2.65である.

実験は河床を平坦に敷き均し，路床勾配を $1 / 400$ に設 定した後通水を開始し, 流量変化に伴う河床波の変形, 水深および流砂量の変化を追跡した. 実験の流量波形は 図-3に示すような正弦波状のもので, 次式で表される.

$$
q_{w}=q_{1}+q_{2} \sin \left\{2 \pi\left(\frac{t}{T_{f}}-\frac{1}{4}\right)\right\}
$$

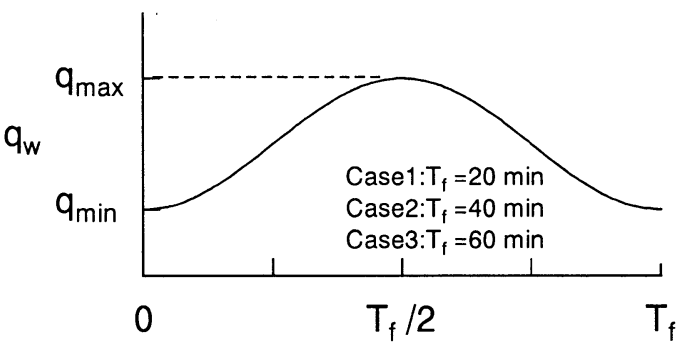

図-3 実験での流量波形

ただし，

$$
q_{1}=\frac{1}{2}\left(q_{\max }+q_{\min }\right), \quad q_{2}=\frac{1}{2}\left(q_{\max }-q_{\min }\right)
$$

ここに, $q_{\max }$ は最大単位幅流量, $q_{\min }$ は最小単位幅流

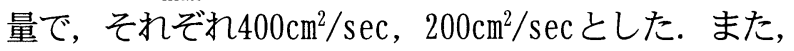
$T_{f}$ は流量の変化周期で，20，40および60分とし，それ ぞれ 3 周期通水した. 以下, 各実験をCase1, Case2およ びCase3 と呼ぶ．実験中はサーボ式水位計と超音波式水 底形状測定器を搭載した台車を, 水路上を往復させて水 面と河床面の縱断形状を測定するとともに，水路下流端 から流出する砂を適時採取して流砂量を測定した. また, 平均河床勾配およびほぼ等流の状態が保たれるように, 予備実験で得られた流砂量の時系列デー夕を基に水路上 流端で給砂を行い，水位計による水面の縦断形状と平均 水面勾配をパーソナルコンピュータでモニタリングしな がら水路下流端でゲートの開度調整を行った. 本研究で は河床波の形状を波長と波高で代表させているが，これ らは河床形状の縱断記録からzero-up-cross法によって求 めた.

\section{3. 流量変化に対する河床波を有する移動床系の 支配方程式}

河床波を有する移動床流れ場では, 河床波の変形に対 する流れの応答が流れの変化に対する河床波の応答に対 して十分に早いと見なせるので, 時々刻々の河床波形状 に応じて抵抗則と流砂量式によって水深, 流砂量の時間 的変化を算定することができる. 本研究における移動床 系を記述するための方程式を以下に示す.

\section{（1）抵抗則式}

抵抗則式は河床波形状を媒介とした次式9)を用いる.

$$
\frac{u_{m}}{u_{*}}=\left\{\frac{4}{7} \Pi^{\prime}\left(\frac{h_{m}}{k_{s}}\right)^{-1 / 4}+\frac{1}{2} C_{D} \Lambda\right\}^{-1 / 2}
$$

ただし，

$$
\left.\begin{array}{l}
\Pi^{\prime}=\left(B^{\prime} / A\right)^{2} C^{1 / 4}, \quad A=8.94, \\
B^{\prime}=(1-\zeta / 2)^{-1} \xi^{-1 / 8}(1-n \lambda)^{3 / 8}\left(1+\lambda^{2}\right)^{3 / 16}, \\
C \approx A^{2}\left\{0.26+\lambda /\left(F_{r} \cdot B\right)^{2}\right\}, \\
B=(1-\zeta / 2)^{-1}\{\xi(1-n \lambda)\}^{-1 / 2}
\end{array}\right\}(4-1)
$$




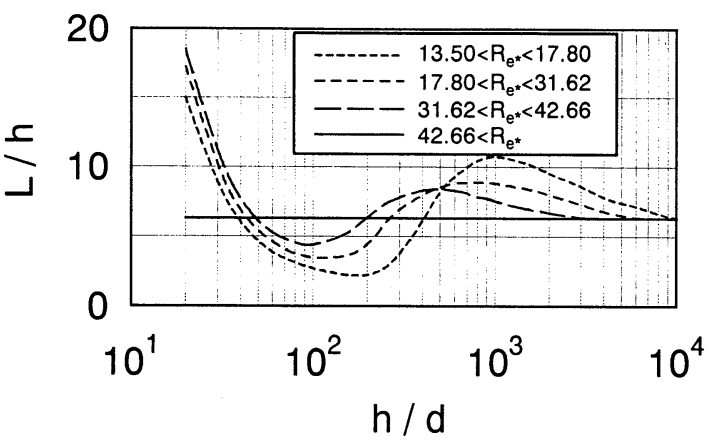

図-4 波長と水理量の関係

$$
\begin{aligned}
C_{D}=\{4(1-4 \lambda)(2+\zeta)\} /\left[(2-\zeta)^{2}\{2+(1-8 \lambda) \xi\}\right] \\
\quad \times[2(1-4 \lambda) \zeta /\{2+(1-8 \lambda) \zeta\}+0.13], \\
\begin{aligned}
\Lambda & =\lambda /(1+\zeta / 2), \quad \zeta=H / h_{m}, \quad \xi=L / h_{m},
\end{aligned} \\
\lambda=H / L, \quad n=L_{s} / H .
\end{aligned}
$$

ここに, $u_{m}$ は平均流速, $u_{*}$ は摩擦速度, $h_{m}$ は平均水 深, $k_{s}$ は等価砂粗度, $F_{r}$ はFroude数, $H, L$ は河床波 の波高および波長である. また， $L_{s}$ はクレスト直下流 の剥離域の長さで, ほぼ $L_{s}=4.25 H$ で与えられる10). なお, 著者らは混合砂河床における河床波の発達過程を 砂粒子の分級との関連で検討した結果 ${ }^{5), 6)}$ から, $d_{90}$ 程 度の粗砂が河床波のスケールを規定する代表粒径 $d_{r}$ に なっていることを明らかにし，このとき等価砂粗度 $k_{s}$ は $2 d_{90}$ で与えられることを示しているので, ここでも これを適用する. ただし, 一様砂に対しては $d_{r}=d_{m}$ と し, $k_{s}=2 d_{m}$ を用いる. 一様砂の場合も多少の分布を もっているので混合砂と同様に扱っても良いが，本文で は平均粒径に着目した扱いを一様砂に適用し, 混合砂に 対して粗砂を導入した場合との比較を行うことによって, 粗砂の効果を考慮することの有効性を明確にすることを ねらっている.

\section{（2）流砂量式}

流砂量の算定には次のMeyer-Peter and Müller型の流砂 量式11を用いる. ただし, 掃流力には河床波形状の効果 を考慮した有効掃流力を用いる.

$$
\left.\begin{array}{c}
\frac{q_{B i}}{p_{i} \sqrt{(\sigma / \rho-1) g d_{i}^{3}}}=8\left(\tau_{* i}^{\prime}-\tau_{* c i}\right)^{3 / 2} \\
q_{B}=\sum_{i=1}^{k} q_{B i}
\end{array}\right\}
$$

ここに, $p_{i}$ は粒径 $d_{i}$ の砂粒子が河床に占める割合, $k$ は粒径階の数, $\tau_{* i}^{\prime}$ は無次元有効掃流力, $\tau_{* c i}$ は無次元 限界掃流力である. なお， $\tau_{* i}^{\prime}$ は次式12)で表される.

$$
\tau_{* i}^{\prime}=\frac{4}{7} \Pi^{\prime}\left(\frac{h_{m}}{k_{s}}\right)^{-1 / 4} \frac{u_{m}^{2}}{(\sigma / \rho-1) g d_{i}}
$$

また， $\tau_{* c i}$ は芦田らの修正Egiazaroff式13)によって，一様 砂の場合は平均粒径に対して岩垣の式によって計算され る.

\section{（3）波高, 波長の変化速度式}

河床波の波高, 波長の時間的変化の予測には中川らの 式）を用いる.

$$
\left.\begin{array}{rl}
\frac{d H}{d t} & =\frac{k_{H}}{1-\rho_{0}} \frac{q_{B}}{L}\left(1-\frac{H}{H_{e}}\right) \\
\frac{d L}{d t} & =\frac{k_{L}}{1-\rho_{0}} \frac{q_{B}}{H}\left(1-\frac{L-L_{0}}{L_{e}-L_{0}}\right)
\end{array}\right\}
$$

ここに, $k_{H}, k_{L}$ は実験定数, $\rho_{0}$ は河床砂の空隙率 $(=0.4), H_{e}, L_{e}$ は波高, 波長の平衡値, $L_{0}$ は初期波 長 $\left(=100 d_{m}\right)$ である. なお, 中川らは増水期では $k_{H}=$ $0.36, k_{L}=0.24$, 減衰期では $k_{H}=0.72, k_{L}=0$ としてい るが, 後述するように減衰期でも波長は漸减しているの でここでは増水期の值 $k_{L}=0.24$ を用いることにする. ま た, $L_{e}$ はYalin ${ }^{14)}$ にならって,

$$
L_{e}=\alpha \cdot h_{m e}
$$

で与える（ $h_{m e}$ は $L_{e}$ に応じた平均水深）。 $\alpha$ は通常 5 程度の一定值に取られることが多いが，ここではより厳 密に, Yalinによる波長と水理量の関係図15)を図-4のよ うに再編した結果を用いて $R_{e^{*}}$ と $h / d$ の関数として与え る.ただし，各曲線間は線形補完して用いる．また， $H_{e}$ は波形勾配が掃流光水深・粒径比で表されている 次のYalin and Karahanの式16)によって算定する.

$$
\lambda_{e}=\frac{H_{e}}{L_{e}}=0.0047\left(\frac{\tau_{*}}{\tau_{*_{c}}}-1\right) \exp \left\{1-\frac{0.0047}{\lambda_{\max }}\left(\frac{\tau_{*}}{\tau_{*_{c}}}-1\right)\right\}
$$

ここに， $\lambda_{\max }$ は最大波形勾配で，Yalinらは実験資料を もとに $\lambda_{\max }$ と $h / d$ の関係を図化しているが, 著者ら17) はこれを次式で表している.

$$
\lambda_{\max }= \begin{cases}-0.058+0.02 \ln \left(\frac{h}{d}\right) ; & \frac{h}{d}>400 \\ 0.062 & ; \frac{h}{d} \geq 400\end{cases}
$$

ただし, 式(10)中の $d$ は代表粒径 $d_{r}$ を用いる.

\section{4. 流量変化に対する河床波の変形過程と移動床 系の応答予測}

\section{(1) 計算方法}

計算手順の概略を図-5に示す．すなわち，ハイドログ ラフを刻み幅 $\Delta t$ のstep状に近似し，各stepの流量に対す る平衡河床波形状（波長, 波高) を, 式(3), 式(8)およ び式(9)に流量, 勾配および粒径を与えて求め, これを この流量区間の収束值として式(3)〜 (7)によって波長, 波高, 水深および流砂量を $\delta t$ ごとに算定するものであ る. なお, 実験は平坦河床からは始めているので初期条 件として $t=0$ で $H=2 d_{m}, L=L_{0}$ を与えた. また本解析 では, Case1に対しては $\Delta t=12$ 秒, $\delta t=2$ 秒, Case2 と Case3に対しては $\Delta t=60$ 秒, $\delta t=10$ 秒とした. 


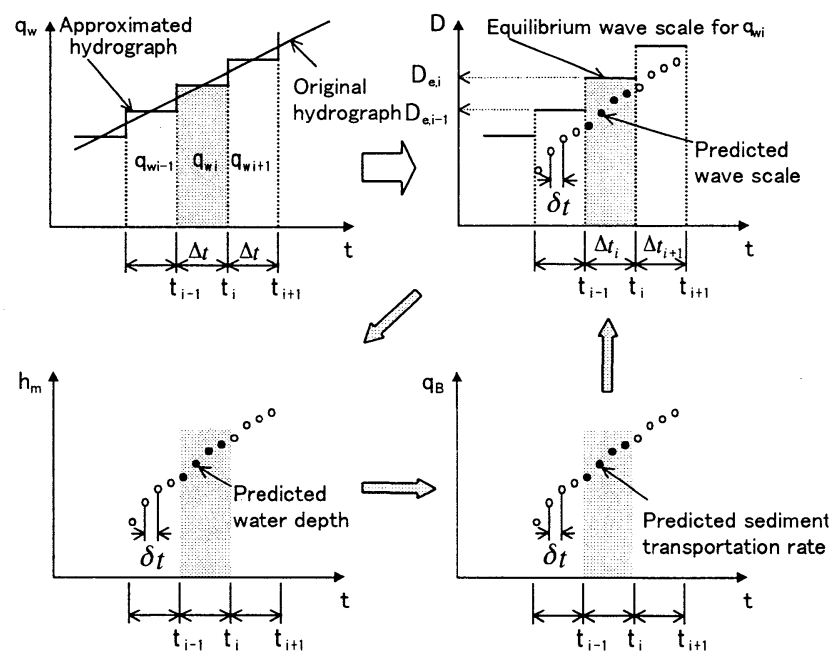

図-5 計算手順

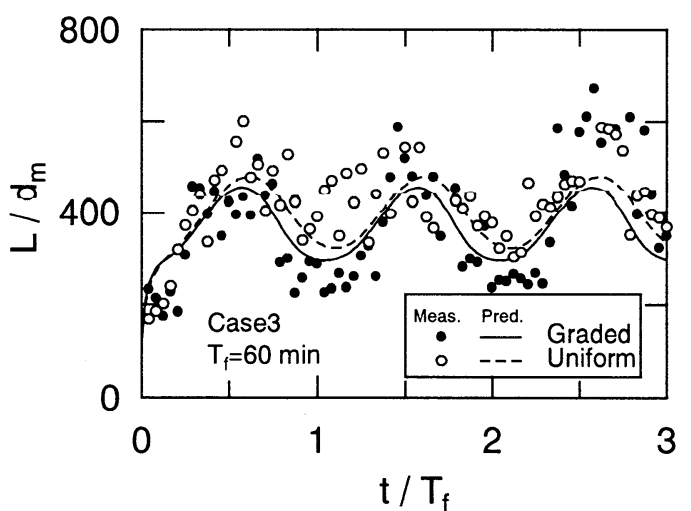

図-6 波長の時間的変化

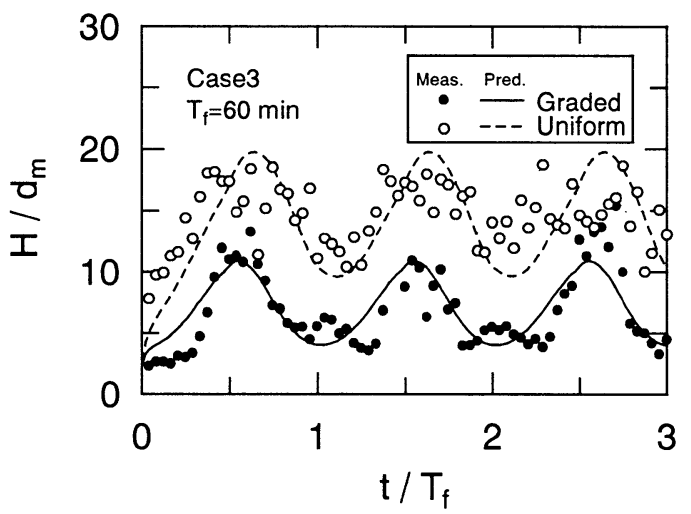

図-7 波高の時間的变化

\section{（2）実験結果および計算結果と考察}

以下, Case3を例にとって流量変化に伴う河床波の変 形過程と流れ場への応答特性の予測結果について述べる. なお，波長，波高，水深および流砂量については平均粒 径で基準化し, 経過時間については流量周期で基準化し ている.

図-6，図-7はそれぞれ波長，波高の時間的変化の計算 結果を実験結果と比較したものである．波長に関しては 一様砂と混合砂で顕著な差異は認められず，両者とも流 量の増減に対応して同様の変化傾向を示している. また, 計算結果もおおむねこれを支持していると見なせる．た だ，減水による波長の莪減期では一様砂の方が混合砂よ

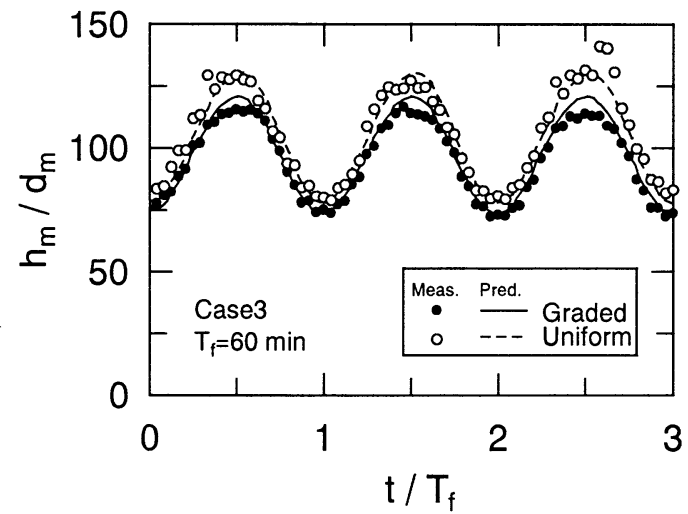

図-8 平均水深の時間的変化

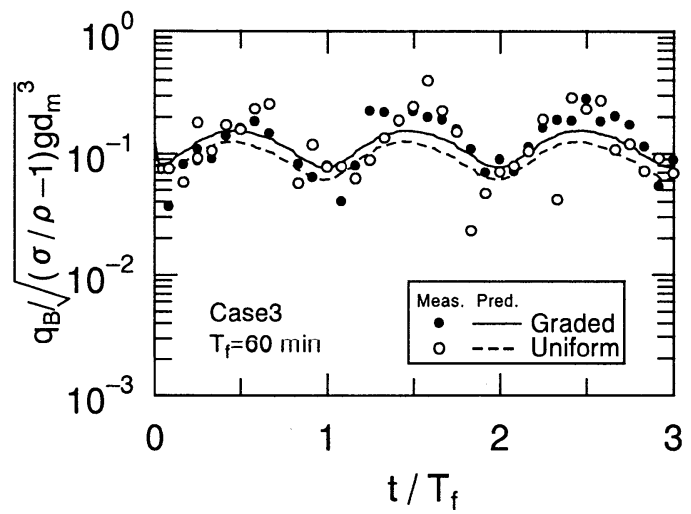

図-9 無次元流砂量の時間的変化

りも変化が若干緩慢な結果となっている．従来，減水期 では波長は一定か，もしくは増加するとされてきたが， 台形状に流量を変化させた著者らの実験結果8) や本実験 結果からはこのような傾向は認め難い。減水期では残存 河床波の埋め戻しによって波長が増加した河床波と新た に発達した短波長の河床波が混在しており，平均波長は その結果として決定される. したがって，前者が卓越す る場合には平均波長は増加傾向を呈するが，後者が卓越 する場合は減少傾向を呈するものと考えられる．いずれ にしても, 今後この条件については詳細に検討する必要 がある. 一方，波高に関しては全通水期間にわたって混 合砂は一様砂よりも低く抑えられており, 両者で顕著な 差異が認められる。これは著者ら5),6),7)が明らかにした ように，混合砂河床において砂粒子が活発に運動してい る場合は河床波の発達や変形に対して粗砂が主要な役割 を担っていることに起因している．計算結果は実験結果 の傾向を適切に説明しており, 粗砂の効果を考慮した代 表粒径を解析に導入することの有用性を示している.

図-8は平均水深の時間的変化の計算結果と実験結果を 示している. 同一位相において一様砂河床の水深が混合 砂河床の水深よりも大きくなっているのは，一様砂河床 の波高が混合砂河床よりも大きいためで，水深に反映さ れる形状抵抗が混合砂河床よりも一様砂河床の方が大き いことを意味している. 水深の算定結果は良好であると 判断でき, 河床波の変形過程を適切に推定できれば事実 上十分な精度で抵抗の予測が可能であるといえる.

図-9は流砂量の時間的変化の計算結果を測定結果とと 

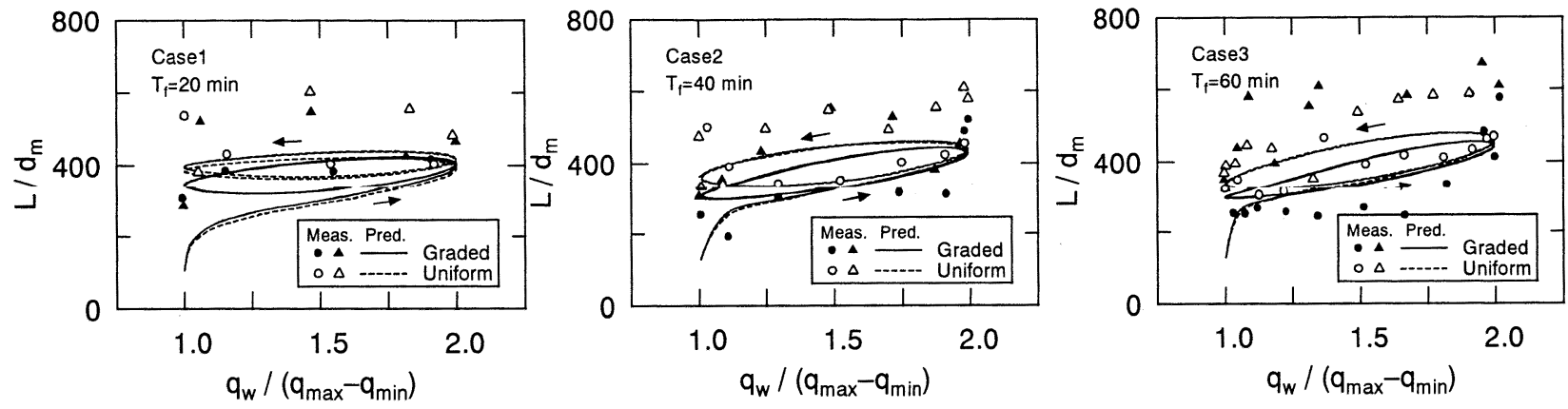

図-10 流量变化に対する波長の応答
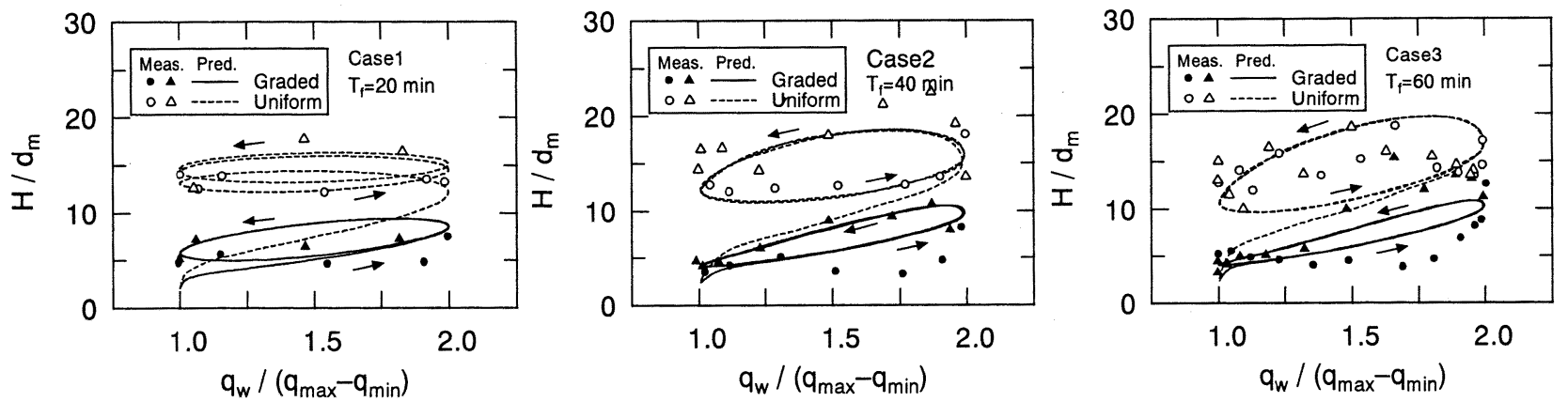

図-11 流量変化に対する波高の応答

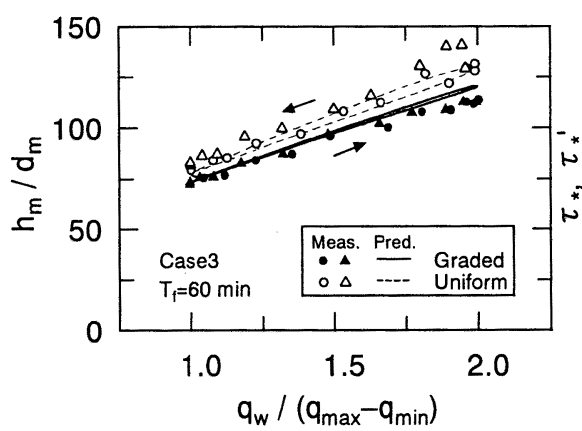

図-12 流量変化に対する水深の応答

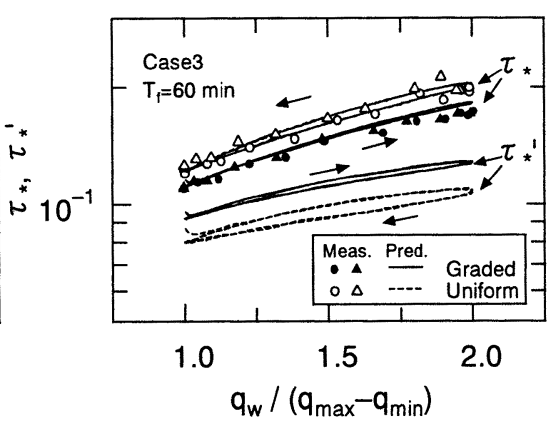

図-13 流量変化に対する掃流力の応答

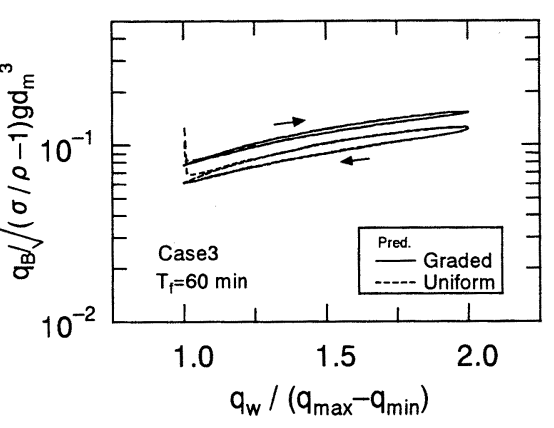

図-14 流量変化に対する流砂量の応答
もに示したものである. 流砂量のピーク付近で計算結果 は測定結果を過小に評価しているが，おおむね実験結果 の傾向を説明していると見なせる.

\section{5. 流量変化に対する移動床系の応答遅れ性状}

本実験では流量変化に対応させて水位を調節し, 絶え ず等流に近い状態を保つことによって不等流効果を除去 しているので, 流量変化のみによる河床波の応答遅れを 単独に抽出することができる.

図-10〜図-12は流量変化に対する波長，波高および水 深の応答関係を示したものである. なお, 計算結果につ いては第 1 周期目から第 3 周期目までを示しているが, 実験值については第 3 周期目のもののみを描点している. 図中, と○は増水期，ムと $\triangle$ は減衰期を表す。ここに 形成されるループの幅は流量変化に対する応答遅れの程 度, すなわち流れ場の変化への追随性を表す. 波長に関 しては実験值は $T_{f}=20$ 分と 40 分では混合砂と一様砂で顕 著な差異はないが， $T_{f}=60$ 分では混合砂の方がループの 幅が大きくなっており，計算結果とは異なる傾向を示し
ている. 一方, 波高に関しては $T_{f}=20$ 分と 40 分では混合 砂の方がループの幅は小さく, また計算曲線もこれを支 持しており, 流量変化に対して追随しやすいことを示し ている. しかし, $T_{f}=60$ 分では一様砂の方が実験值の ループが小さく, 計算結果とは逆の傾向を示している. 流量周期によるこのような相違の原因についてはより長 周期の実験を行う等, さらに検討する必要がある. また, 水深については $T_{f}=60$ 分の場合のみを示したが, 混合砂 のループの幅は一様砂よりも小さく, 流量の増減水に対 する履歴性は弱いといえる. なお，ここに示したループ はいずれも左回りである.

図-13，図-14は流量変化に対する平均粒径で基準化さ れた無次元掃流力と無次元有効掃流力および流砂量の応 答関係を示したものである. 無次元掃流力は混合仯, 一 様砂とも流量の増減に対して左回りのループを形成して おり，増水期よりも減衰期の方が全抵抗は大きい。しか し, 流砂量に影響する無次元有效掃流力は右回りのルー プを示しており，増水期よりも減水期の方が小さい．し たがって, 流砂量の変化はこれに対応して右回りのルー プを描くことになり，増水期よりも減衰期の方が流砂量 

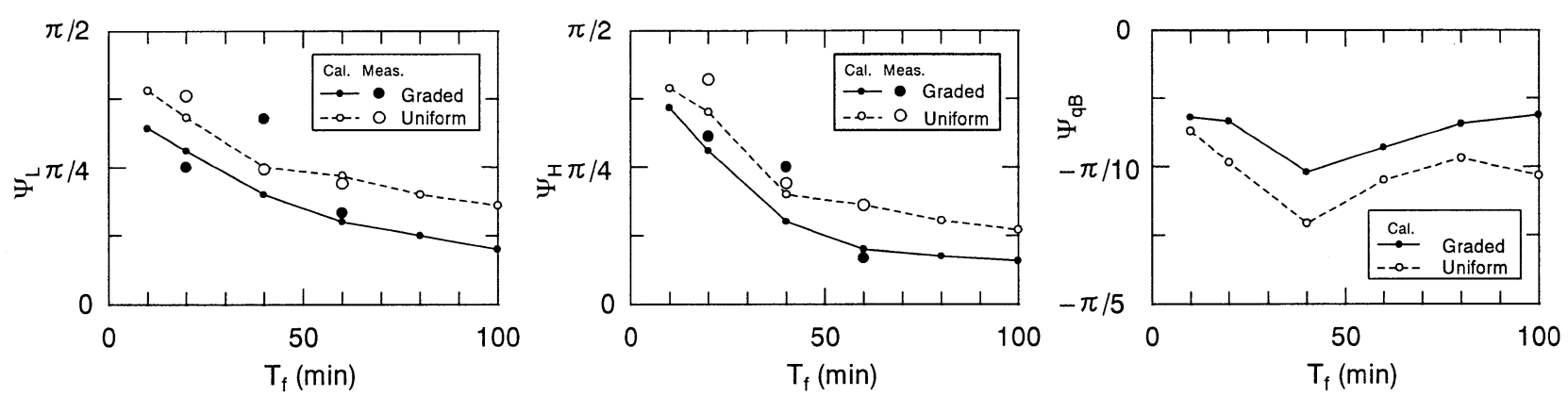

図-15 波長, 波高および流砂量の位相遅れ

は小さくなると推察される.

図-15は流量のピーク時刻を位相 0 として, 第 3 周期 目における波長，波高および流砂量のピークの現れる位 相 $\Psi$ と流量周期の関係を示したものである. 同一の流 量周期に着目すると, 波長と波高に関しては $T_{f}=40 \mathrm{~min}$ の実験ケースで混合砂が一様砂よりも大きな位相差を示 しているものの，それ以外では混合砂の方が位相は小さ いことがわかる．一方，流砂量に関しては位相が負と なっており, 流量のピーク時刻よりも前に流砂量のピー クが現れることを示している. これは摩擦抵抗のピーク と対応しており，ピーク後は流量増加によって全抵抗が 増加しても摩擦抵抗は減少し，抵抗の増加分は形状抵抗 に受け持たれていると推察される. また，波長や波高と 同様，一様砂よりも混合砂の方が位相は小さくなってい るが, 両者とも $T_{f}=40$ 分で極小值を示しており, ここで 流砂量の（負の）遅れが最大となっている.

\section{6. 結 言}

本研究では, 混合砂河床と一様砂河床に対して, 正弦 波状流量変化による河床波の変形過程と移動床系の応答 予測を行うとともに，応答遅れの特性について検討した.

連続的に流量が変化する場でも混合砂河床では一様砂 河床に比べて河床波の波高が低く抑えられたが， $d_{90}$ 程 度の粗砂を代表粒径として移動床系の支配方程式に導入 することによってこれを適切に算定することができると ともに水深や流砂量についてもおおむね予測し得ること が示された. また，流量の増減に対して波長，波高，水 深および全掃流力は左回りのループを描くが，有效掃流 力上流砂量は右回りのループを描き，流砂量のピークは 流量のピークよりも早く現れる可能性のあることが示さ れた.

前論文 ${ }^{8)}$ では単一の台形状流量波形の下での河床波の 変形と移動床系の応答を扱い，これらの特性とその予測 について検討したが，本文では周期的に変化する正弦波 状の流量波形の下での現象を扱った. これによって，同 一流量波形の繰り返しに対する現象の追随性が本解析に よっておおむね適切に評価されること，またピーク流量 時からの応答遅れが一様砂よりも混合砂の方が小さいこ と等が示された.
参考文献

1）芦田和男, 中川 一, 加藤 均 : 流量变化に伴う河床波 の応答に関する研究, 京都大学防災研究所年報, 第25号 B-2, pp. 473-491, 1982.

2）中川博次, 辻本哲郎, 竹束正孝: 河床波を伴う非定常流 れの特性, 第27回水理講演会論文集, pp. 665-671，1983.

3）澤井健二 : 周期的流量変化に伴う河床波の応答に関する 実験，第29回水理講演会論文集，pp.473-478，1985.

4）鈴木幸一，道上正䂓：Dunesの波高およびそれに及ぼす混 合砂礫の影響について, 第23回水理講演会論文集, pp. 151-156, 1979.

5）三輪 浩, 大同淳之: 河床粒子の分級と河床波の形成過 程の相互作用に関する実験的研究, 水工学論文集, 第 35 巻, pp. 403-410, 1991.

6) Miwa, H. and Daido, A.: Sand wave development with sediment sorting, Journal of Hydroscience and Hydraulic Engineering, JSCE, Vol.10, No.2, pp.39-50, 1992.

7）三輪 浩, 大同淳之: 河床波の変形に及ぼす混合砂の分 級効果, 水工学論文集, 第41巻, pp. 901-908， 1997.

8）三輪 浩, 大同淳之 : 混合砂河床における流量変化に伴 亏河床波の応答予測, 水工学論文集, 第42巻, pp. 10931098, 1998.

9）大同淳之, 三輪 浩, 矢野定男 : 河床波の平衡波高, 第 50回土木学会年次学術講演会概要集 II (A), pp. 490-941, 1995.

10）三輪 浩, 大同淳之: 河床波上の流れの特性之流水抵抗 の評価, 舞鶴工業高等専門学校紀要, 第28号, pp. 99-106, 1993.

11) Meyer-Peter, E. and Müller, R.: Formulas for bed-load transport, Proceedings of II Congress, IAHR, pp.39-64, 1948.

12）三輪 浩, 大同淳之: 河床波による流水抵抗と流砂量, 水工学論文集, 第36巻, pp. 123-130, 1992.

13）芦田和男，道上正䂓：移動床流れの抵抗と掃流砂量に関 する基礎的研究，土木学会論文集，第206号，pp. 59-69, 1972.

14) Yalin, M. S.: Geometrical properties of sand waves, Journal of Hydraulics Division, ASCE, Vol.90, No.HY5, pp.105-119, 1964.

15) Yalin, M. S.: Mechanics of Sediment Transport, 2nd edition, Pergamon Press, Oxford, 1977.

16) Yalin, M. S. and Karahan, E.: Steepness of sedimentary dunes, Journal of Hydraulics Division, ASCE, Vol.105, No.HY4, pp.381-392, 1979.

17）三輪 浩，大同淳之：河床波を有する移動床流れ場の抵 抗予測之流砂量, 舞鶴工業高等専門学校紀要, 第 30 号, pp. 432-54, 1995. 